\title{
釧路市における既存構造物への 津波避難に関する基礎的検討
}

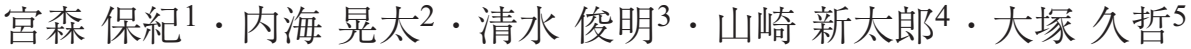 \\ 1正会員＼cjkstart北見工業大学准教授＼cjkstart社会環境工学科（广090-8507 北見市公園町 165） \\ E-mail miyamoya@mail.kitami-it.ac.jp \\ 2学生員 北見工業大学 大学院社会環境工学専攻（ $=090-8507$ 北見市公園町 165) \\ E-mailm1252200020@std.kitami-it.ac.jp \\ 3学生員 北見工業大学 社会環境工学科（广090-8507 北見市公園町 165） \\ E-mailfa090080@std.kitami-it.ac.jp \\ 4非会員 北見工業大学助教 社会環境工学科（ $\bar{T} 090-8507$ 北見市公園町 165） \\ E-mail yamasaki@mail.kitami-it.ac.jp \\ 5フェロー 九州大学大学院教授 工学研究院社会基盤部門（广819-0395 福岡市西区元岡 744） \\ E-mail otsuka@doc.kyushu-u.ac.jp
}

\begin{abstract}
本研究は北海道釧路市を対象として，既往の津波災害ならびに 2012 年に公表された最大の想定津波につ いて纏めるとともに，今後の減災対策の構築に向け基礎的な検討を行ったものである. 釧路市では明治期 以降は人的被害を伴う津波災害は報告されていないものの，それ以前には大規模な津波が発生した可能性 がある，想定される最大津波に対して，既存の建築物や道路施設を緊急で一時的な避難場所として用いる ことについて現地調査を踏まえた検討を行った。その結果, 建物への一時的な避難や自動車による道路施 設への避難を効果的に行えば，人的被害を防止することはおおむね可能と思われる結果が得られた。
\end{abstract}

Key Words: tsunami evacuation, Kushiro City, tsunami evacuation building, evacuation highway

\section{1.はじめに}

北海道東部太平洋岸の釧路市は，これまでもプ レート境界型の規模の大きい地震が繰り返し発生し ており, 大津波の発生も懸念されるとともに対策が 行われてきた。一方, 2011 年 3 月 11 日に発生した 東北地方太平洋沖地震を契機に, 各地で津波想定の 見直しが進められている。北海道防災会議により 2012 年 6 月に公表された津波浸水予測図 ${ }^{1)}$ では, 釧 路市では市街地の広範囲が浸水するとされ，対策の 大幅な見直しが必要となっている。

津波に対する防災対策としては, 防潮堤の整備, 居住地域の高台移転や高台化, 避難などがあるが, 釧路市ではこれまで避難対策を中心としてハザード マップの作成や津波緊急一時避難施設の指定を行っ てきた。しかしながら, 最新の津波浸水予測図では, 浸水範囲に居住する人口は 10 万人以上となる。こ のような巨大津波に対しては, 行政主導の避難誘導 では十分な対応はできない，住民の自助による避難
場所の確保と避難行動の実行を基本に中長期的な都 市構造の改善や, 周辺地域との連携により減災を図 ることが望まれる。

本研究は，釧路市における巨大津波に対寸る減災 対策の推進に貢献するための基礎的検討の一環とし て, 現状の釧路市街地の状況を概観するとともに, 既往の津波被害について文献調査を行った。ささらに 公表された津波浸水予測図で想定された津波に対し て，一部地域を対象として住民が緊急的に避難でき るような建物や土木施設の現状を調查し, 避難場所 としての利用可能性を検討したのでその結果を報告 するものである。

\section{2. 釧路市で予測される津波被害}

\section{（1）釧路市の地理}

釧路市は, 北海道の東部太平洋岸に位置し, 人口 は北海道内 4 位の約 18 万人で道東の拠点都市であ 


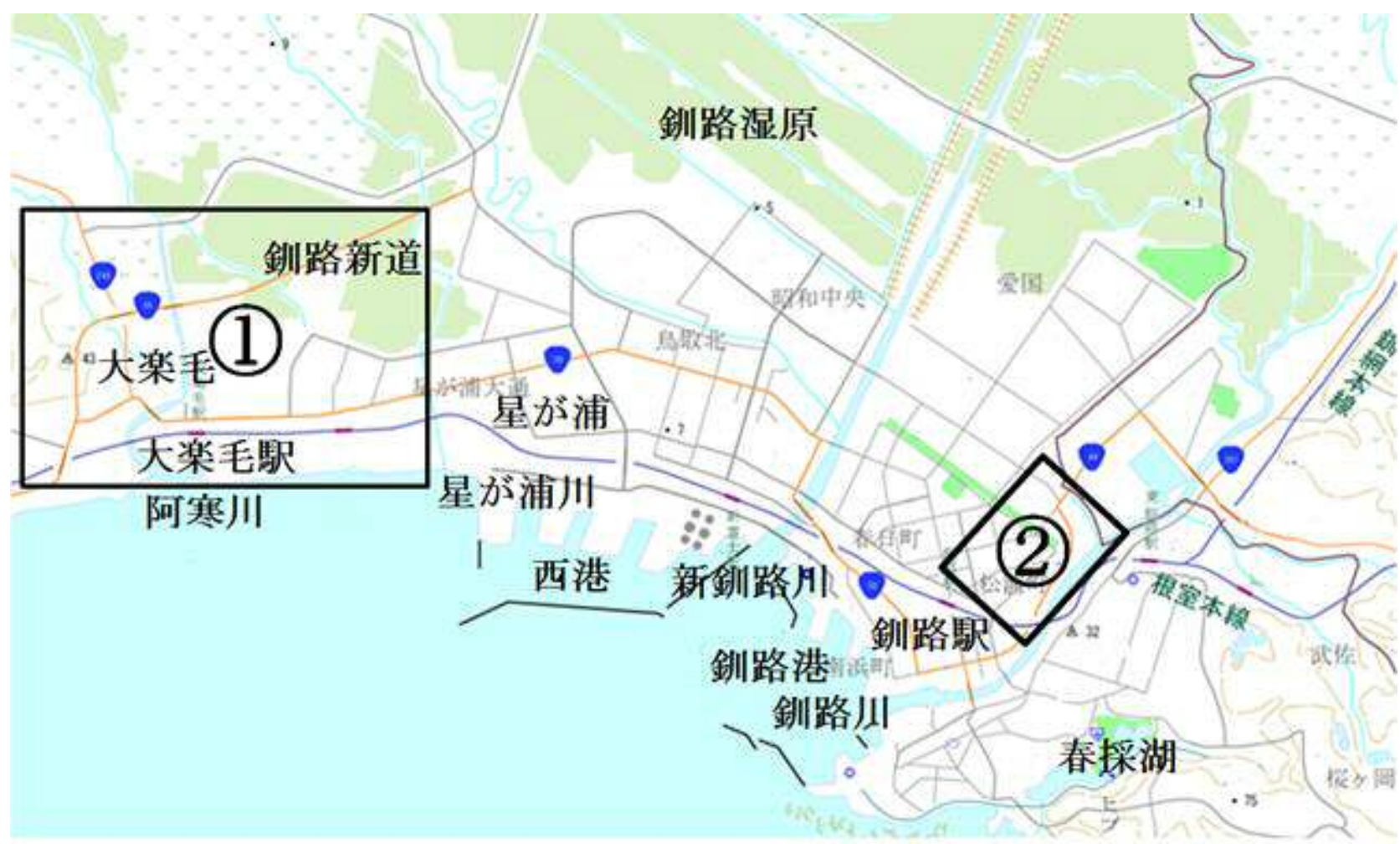

図-1＼cjkstart釧路市の地理 ${ }^{2}$

表-1＼cjkstart釧路市の既往津波被害

\begin{tabular}{|c|c|c|c|c|c|}
\hline 発生日 & 地震·津波名 & 震央 & マグニチュード(M) & 津波高 (m) & 釧路市の主な被害 \\
\hline $1960 / 5 / 23$ & チリ地震津波 & チリ沖 & 8.5 & 3.4 & $\begin{array}{c}\text { 住宅の床上浸水 } 43 \text { 戸 } \\
\text { 住宅の床下浸水 47戸 } \\
\text { 漁船破損 65隻 }\end{array}$ \\
\hline $1968 / 5 / 16$ & 1968年十勝沖地震 & 三陸沖 & 7.9 & 1.1 & 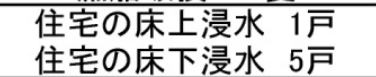 \\
\hline $1994 / 10 / 4$ & 北海道東方沖地震 & 北海道東方沖 & 8.1 & 1.6 & $\begin{array}{l}\text { 住宅の床上浸水 } 3 \text { 戸 } \\
\text { 住宅の床下浸水 2戸 }\end{array}$ \\
\hline $2003 / 9 / 29$ & 2003年十勝沖地震 & 十勝沖 & 8.0 & 1.2 & \\
\hline $2011 / 3 / 11$ & 東北地方太平洋沖地震 & 三陸沖 & 9.0 & 2.3 & $\begin{array}{c}\text { 住宅の床上浸水 68戸 } \\
\text { 住宅の床下浸水 150戸 } \\
\text { 住宅以外の建物床上浸水 } \\
\text { 350棟 } \\
\text { 榲 }\end{array}$ \\
\hline
\end{tabular}

る。図-1のように市街地は東西の丘陵地に挟まれた 釧路川，阿寒川の下流域に発達しており，北側には 日本で最も広い釧路湿原, 南には太平洋が広がる。 主要産業は, 後背地を含む農林業, 沖合・遠洋漁業, 食品加工や製薬，製紙業であり，国内唯一となった 坑内掘り炭鉱も有する。交通機関は, 釧路港は国際 バルク戦略港湾に指定され，釧路空港は国管理の拠 点空港に指定されているものの, 高規格道路は整備 中で開通していない3）。

\section{(2) 既往の津波被害}

表-1 は参考文献 4）～10）に基づき，記録が残る明 治期以降の釧路市における津波被害をまとめたもの である。当地における津波被害は浸水による土地や 建物の被害が大半で人的被害は記録されていない.
2011 年東北地方太平洋沖地震による津波について は, 釧路市測量設計事業協会が釧路港周辺の浸水状 況調査を行っており，図-2のように沿岸部を中心と して最大 $1.5 \mathrm{~m}$ 程度の浸水被害があった ${ }^{11)}$. 図-2の 調査対象範囲外でも，釧路川支流のアセッツリ川で も津波の遡上と周辺住宅地への浸水被害が報告され ている12).

明治期以前の釧路市における地震・津波痕跡につ いては，参考文献 13）に纏められている。当地では 文書で津波の状況を詳細に記録したものはないが, アイヌの口碑伝説が採録されている14),15)。このう ち高清水 ${ }^{15)}$ は北海道の津波に関するアイヌの口碑伝 説全般について調査と可能性の評価を行っており, 釧路での津波については図-3のように具体的な地名 と浸入経路を示し口碑伝説に信頼性があることを示 


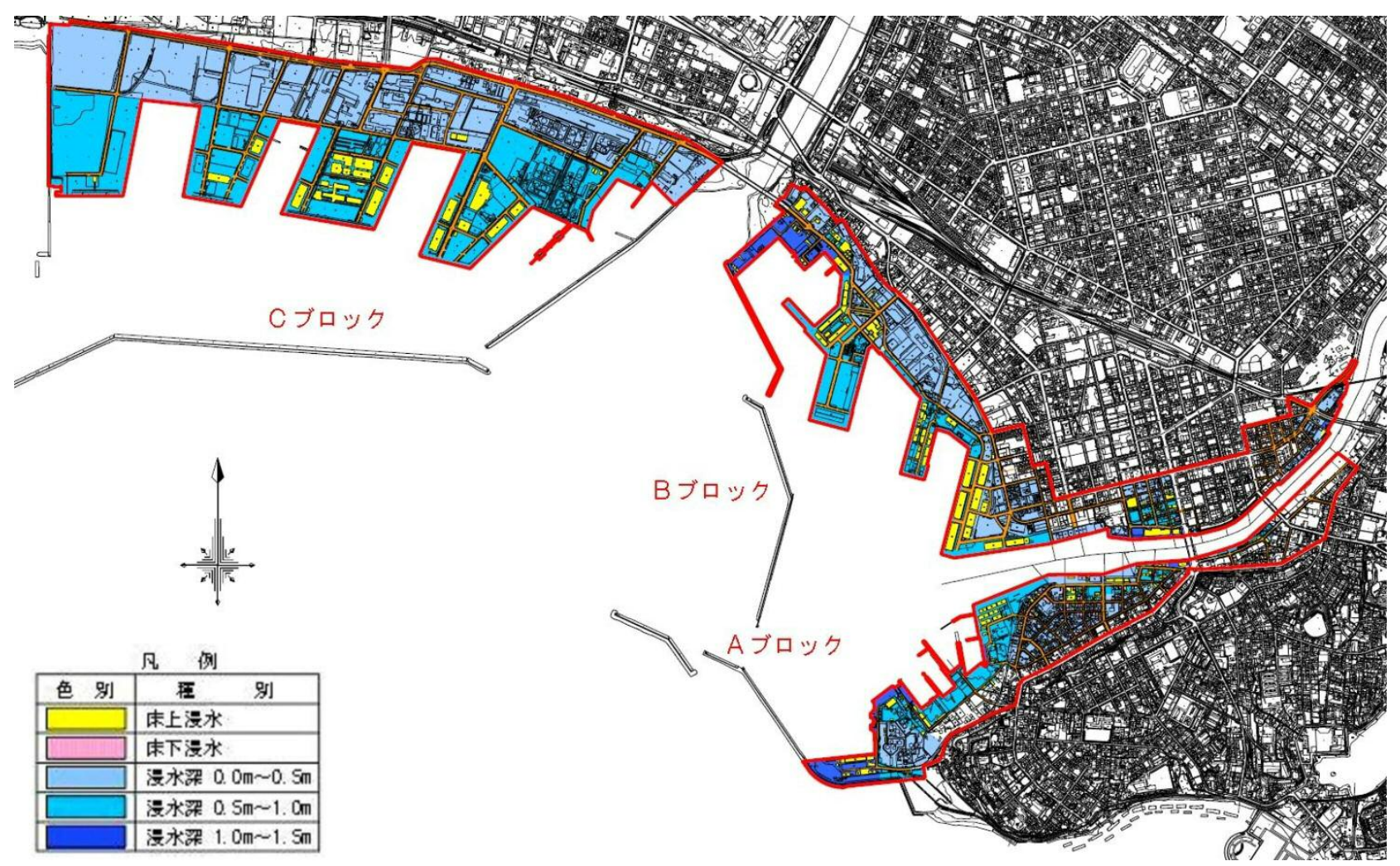

図-2 2011 年東北地方太平洋沖地震津波の浸水状況 ${ }^{11)}$

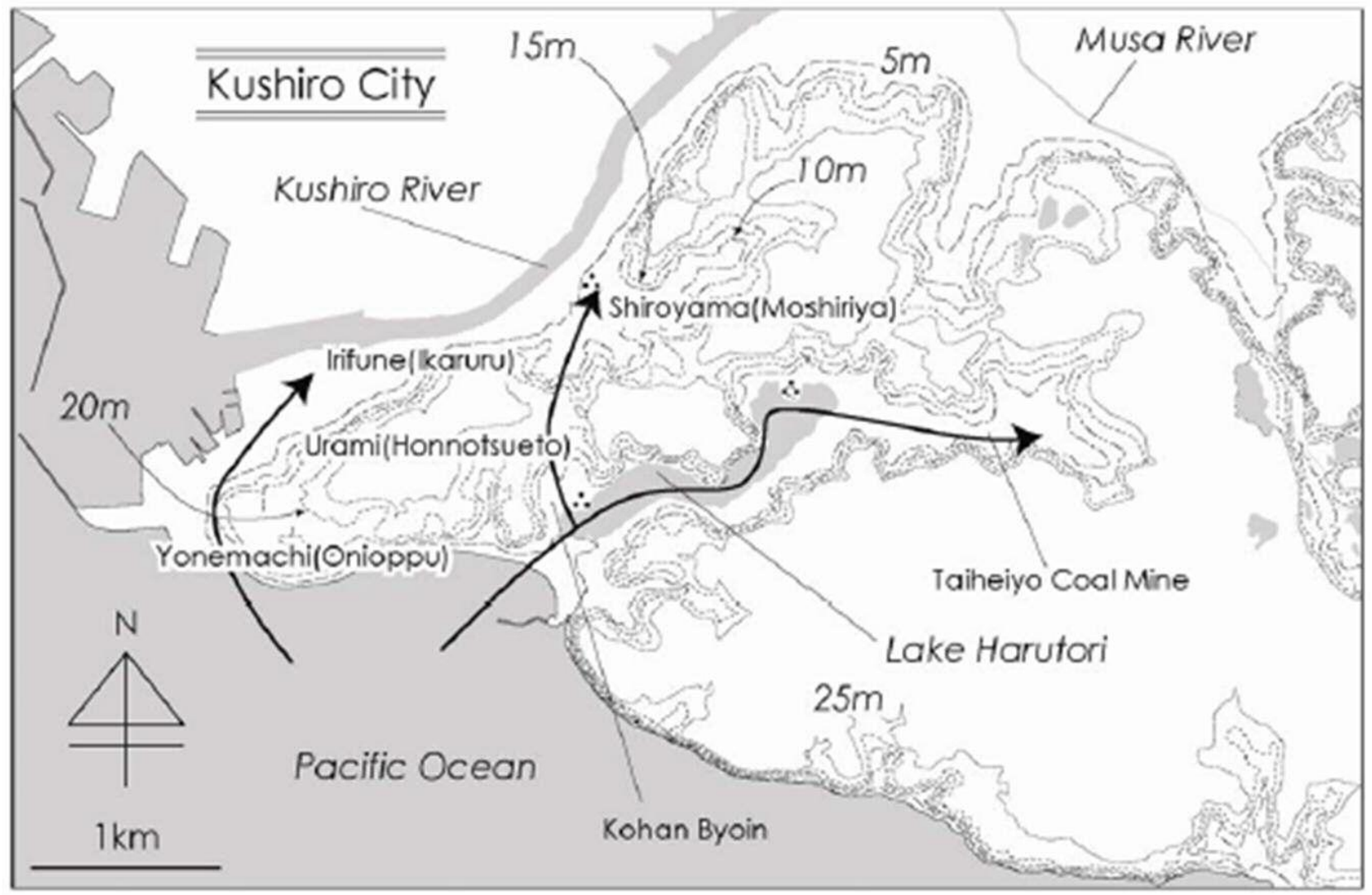

図-3 アイヌの口碑伝説による津波 ${ }^{15)}$

唆している。これらの口碑伝説によると, 時代は不 詳ながら, 大昔, 津波は春採湖に浸入して最奥部ま で到達するとともに，春採湖北西岸の柏木から釧路
川左岸の城山に流れ出たとされている。春採湖周辺 にはアイヌの砦跡やそれ以前の遺跡が多くあること から, 古くから人が定住し津波の目撃談も残された 


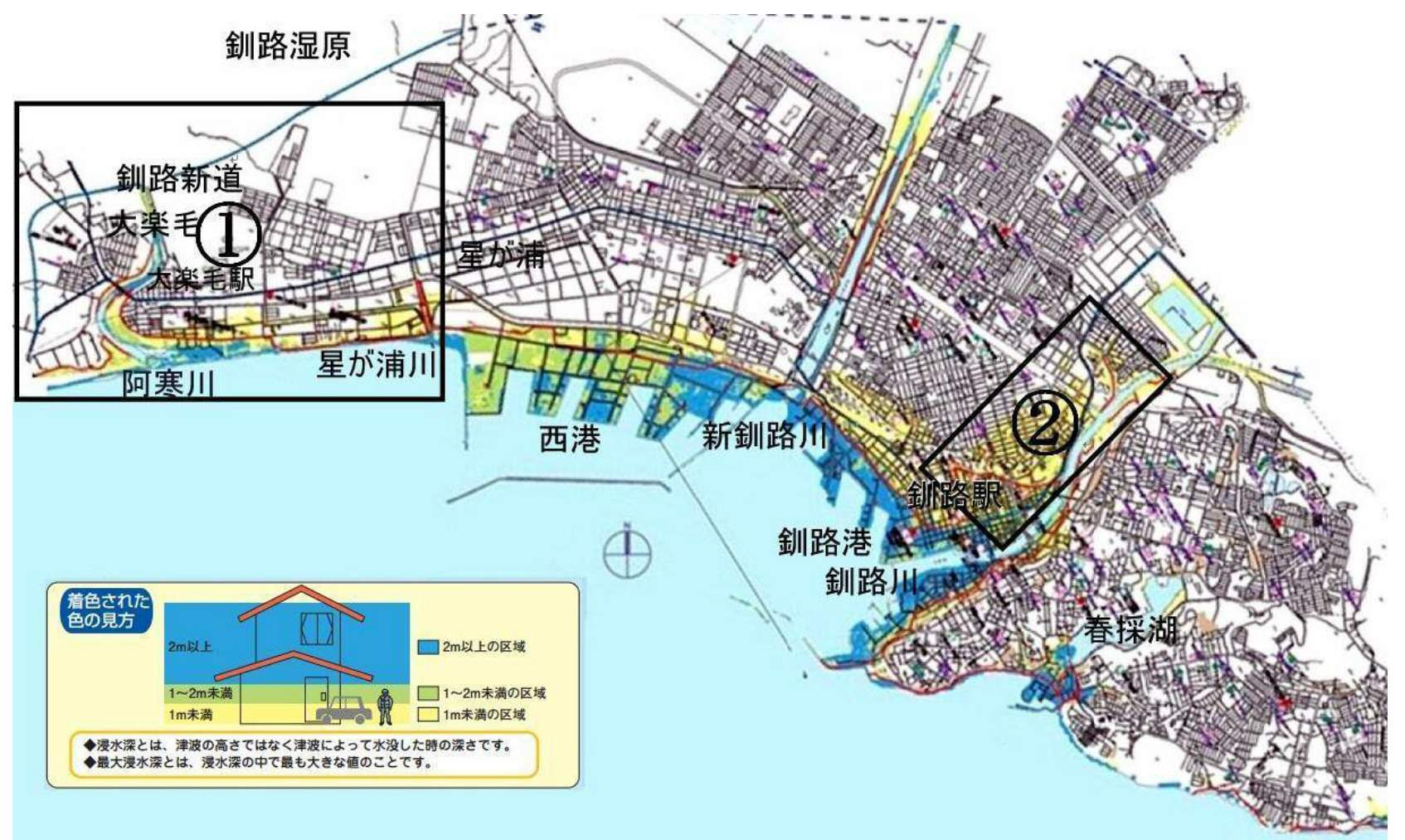

図-4 500 年間隔地震津波ハザードマップ22)

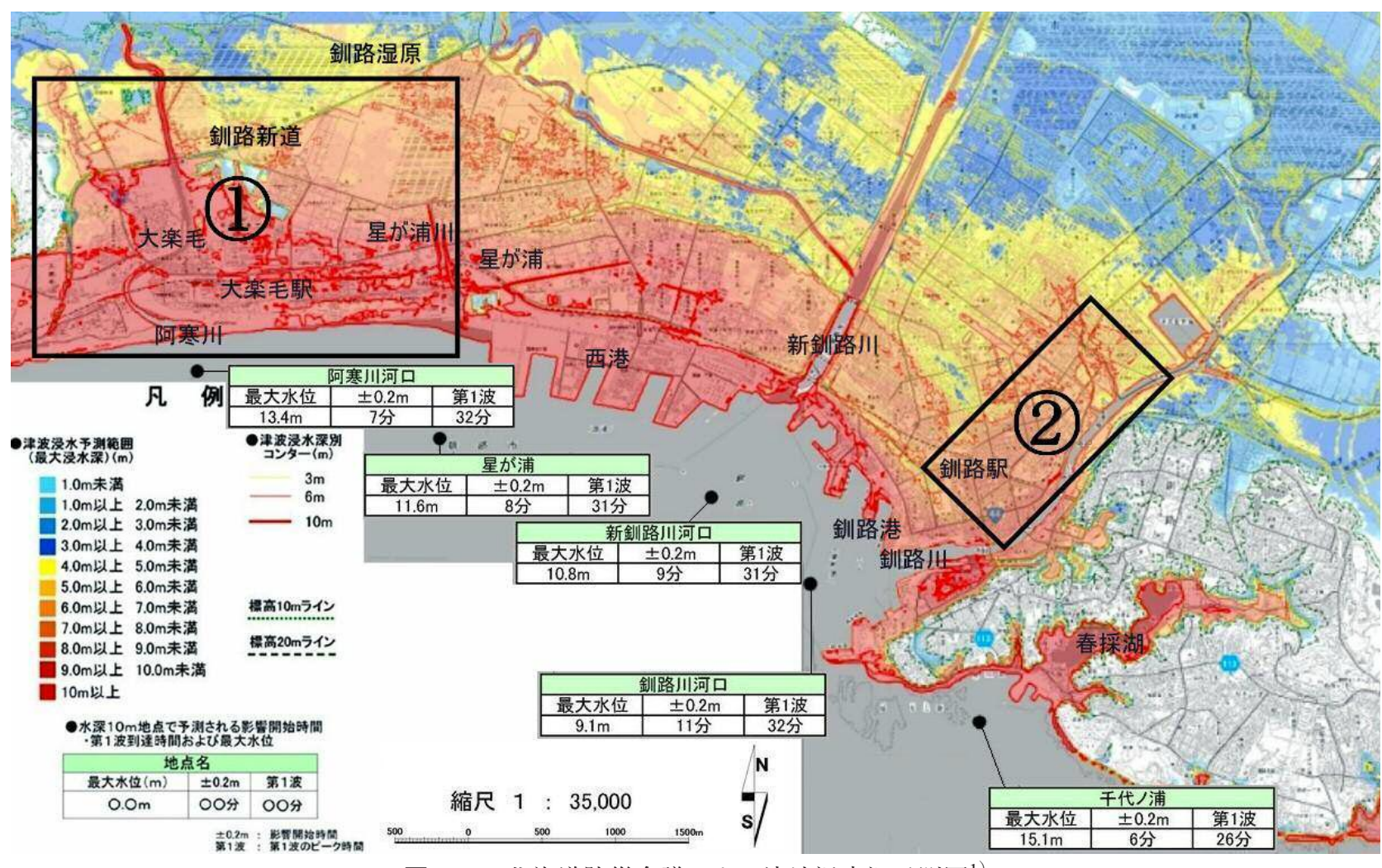

図-5 北海道防災会議による津波浸水深予測図 ${ }^{1}$

可能性がある。参考文献 16)，17）では春採湖のボー リングコアから津波の発生年代を推定し, 13 世紀と 17 世紀に大規模な津波があったことを示す結果を得 ている。一方現在は市街地となっている釧路川より 西の海岸部は, 都市化される前は標高数 $\mathrm{m}$ の砂丘で
背後の湿原よりやや高い地形だった。この砂丘地に は擦文文化期の遺跡が報告されているが18）, 明治期 に鳥取県士族により開拓がはじまるまでの数百年間 は定住者もほとんどなかったと思われる19）。なお， 擦文文化は北海道に特有の文化区分で本州の文化区 
表-2＼cjkstart歩行速度 $P_{1}$

\begin{tabular}{|c|c|}
\hline \multirow{3}{*}{$P_{1}$} & 老人単独歩行: $1.3 \mathrm{~m} / \mathrm{sec}$ (平均) \\
\cline { 2 - 3 } & 群衆歩行:0.88 $1.29 \mathrm{~m} / \mathrm{sec}$ (晴眼者) \\
\cline { 2 - 2 } & 障害者の歩行:0.91m/sec \\
& (平均, 車いす利用の場合) \\
\hline
\end{tabular}

表-3 津波最大高さ $L_{t}$

\begin{tabular}{|c|c|}
\hline 対象地区 & 津波最大高さ (計算使用数値) $(\mathrm{m})$ \\
\hline \hline 大楽毛地区 & $10(12)$ \\
\hline 釧路川右岸地区 & $8(9)$ \\
\hline
\end{tabular}

分では飛鳥時代から平安時代に相当する20).

\section{（3）予想される津波被害}

釧路市では従来根室沖から十勝沖を震源とするマ グニチュード 8.6 のいわゆる 500 年間隔地震などを 想定したハザードマップの整備, 避難施設の指定を 行ってきた ${ }^{21)}$, 22). 500 年間隔地震津波ハザード マップ（図-4）では沿岸部の港湾地区では浸水深 $2 \mathrm{~m}$ 以上, 市街地中心部から釧路川下流部右岸では浸水 深 $1 \sim 2 \mathrm{~m}$ 未満あるいは $1 \mathrm{~m}$ 未満とされている。ま た, 西部の大楽毛（おたのしけ）地区では沿岸部で浸 水深 $1 \mathrm{~m}$ 未満と予測されている。避難施設としては 広域避難場所 126 箇所, 指定避難場所 181 箇所に加 え, 津波緊急一時避難施設として, ホテル, 小・中学 校，民間施設 42 箇所を市街地中心部などに指定して いる.

一方，北海道防災会議が 2012 年 6 月に公表した報 告書 ${ }^{1)}$ では, 市内のかなり広範な地域への浸水が予 測されている (図-5)，沿岸部各所の沖合の水深 $10 \mathrm{~m}$ 地点での最大水位は 9.1〜 15. 1m で到達時間は約 30
分である。釧路川より西側では全域で浸水が予測さ れ，浸水深は海岸近くでは $10 \mathrm{~m}$ 以上，内陸側でも $3 \mathrm{~m}$ 以上となっており，津波は市街地後背の湿原にまで 到達する。東部の春採湖周辺では海に面した千代の 浦では $10 \mathrm{~m}$ 以上，最奥部の湖東岸でも 6 $10 \mathrm{~m}$ 以上 の浸水深となっている。また釧路川を遡上する津波 が, 左岸の城山, 貝塚で浸水し, 市街地東側の高台を 取り囲むようになる。この予測結果は上述のアイヌ の口碑伝説と整合的である。図-5 から浸水範囲を大 まかに読み取り，各町の人口拉よび面積データ23),24) から浸水面積と浸水範囲内の人口を概算した。浸水 範囲は釧路市（市町村合併前の旧釧路市）の面積の 約 8 割, 人口は 10 万人以上となった。住民 10 万人 が地震発生後 30 分間で市の東西の高台に避難する ことは非常に困難である。また避難誘導を行政が組 織的に行うことは, 人員数, 情報や指示の伝達時間, 職員の被災可能性を考えると必ずしも合理的ではな い。したがって，当面は住民の自助による被害軽減 を図るとともに，中長期的に都市構造の改善や，避 難道路の整備などを進めることが必要と考えられ る。本研究ではこのような予測される最大級の津波 被害に対する被害軽減策の一環として, これまでは 公的に避難施設として指定されていない, 既存の構 造物を活用することについての基本的な検討を行 う.

\section{3. 避難可能施設の検討}

\section{（1）調査対象地域}

本研究では，釧路市に巨大津波が来襲した場合の 浸水面積が広大で，避難が必要な人口も多いことか ら，住民の自助的避難策として，既存の中高層建築

表-4 選定した避難場所（大楽毛地区）

\begin{tabular}{|c|c|c|c|c|c|c|c|c|}
\hline 町区分 & コード & 建物の高さ (m) & 建築物区分 & 屋上の有無 & L1 & $\mathrm{L} 2$ & 避難可能距離 & 建設年(1980年以降) \\
\hline \multirow{5}{*}{ 大楽毛西 } & \multirow{5}{*}{$\begin{array}{l}\text { A1 } \\
\text { A2 } \\
\text { A3 } \\
\text { A4 } \\
\text { A5 }\end{array}$} & \multirow{5}{*}{$\begin{array}{l}16.5 \\
12.0 \\
15.6 \\
14.5 \\
14.5\end{array}$} & \multirow{2}{*}{ 大学及び専門学校 } & \multirow{2}{*}{$\begin{array}{l}0 \\
0\end{array}$} & \multirow{3}{*}{$\begin{array}{l}489 \\
489 \\
489\end{array}$} & \multirow{2}{*}{$\begin{array}{l}556 \\
764\end{array}$} & \multirow{2}{*}{$\begin{array}{l}489 \\
489\end{array}$} & \multirow{2}{*}{$\begin{array}{l}\text { 不明 } \\
\text { 不明 }\end{array}$} \\
\hline & & & & & & & & \\
\hline & & & \multirow{3}{*}{ 共同住宅 } & $x$ & & 304 & 304 & $x$ \\
\hline & & & & $x$ & 489 & 236 & 236 & $x$ \\
\hline & & & & $x$ & 489 & 225 & 225 & $x$ \\
\hline \multirow{5}{*}{ 大楽毛 } & \multirow{5}{*}{$\begin{array}{l}\text { B1 } \\
\text { B2 } \\
\text { B3 } \\
\text { B4 } \\
\text { B5 }\end{array}$} & \multirow{5}{*}{$\begin{array}{l}15.9 \\
12.0 \\
13.1 \\
13.1 \\
13.1\end{array}$} & $\begin{array}{c}\text { 病院 } \\
\end{array}$ & $\mathrm{O}$ & 489 & 475 & 475 & $\mathrm{O}$ \\
\hline & & & 中学校及び高校 & 0 & 489 & 400 & 400 & 不明 \\
\hline & & & \multirow{3}{*}{ 共同住宅 } & & 489 & 195 & 195 & $x$ \\
\hline & & & & $\mathrm{O}$ & 489 & 202 & 202 & $x$ \\
\hline & & & & 0 & 489 & 205 & 205 & $x$ \\
\hline 大楽毛北 & $\mathrm{C} 1$ & 16.6 & 高校 & 0 & 489 & 440 & 440 & $\mathrm{O}$ \\
\hline 大楽毛南 & D1 & 12.0 & 大学及び尃門学校 & 0 & 489 & 626 & 489 & $x$ \\
\hline 星が浦南 & E1 & 13.9 & 処理施設 & 0 & 489 & 757 & 489 & 不明 \\
\hline 星が浦大通り & F1 & 13.1 & 共同住宅 & $\mathrm{O}$ & 489 & 199 & 199 & 不明 \\
\hline \multirow{6}{*}{ 釧路新道 } & G1 & 9.1 & \multirow{6}{*}{ （橋梁） } & & 489 & & 489 & \multirow{6}{*}{$\begin{array}{l}0 \\
0 \\
0 \\
0 \\
0 \\
0\end{array}$} \\
\hline & G2 & 7.8 & & & 489 & & 489 & \\
\hline & G3 & 8.6 & & & 489 & & 489 & \\
\hline & G4 & 8.4 & & & 489 & & 489 & \\
\hline & G5 & 6.1 & & & 489 & & 489 & \\
\hline & G6 & 5.6 & & & 489 & & 489 & \\
\hline
\end{tabular}




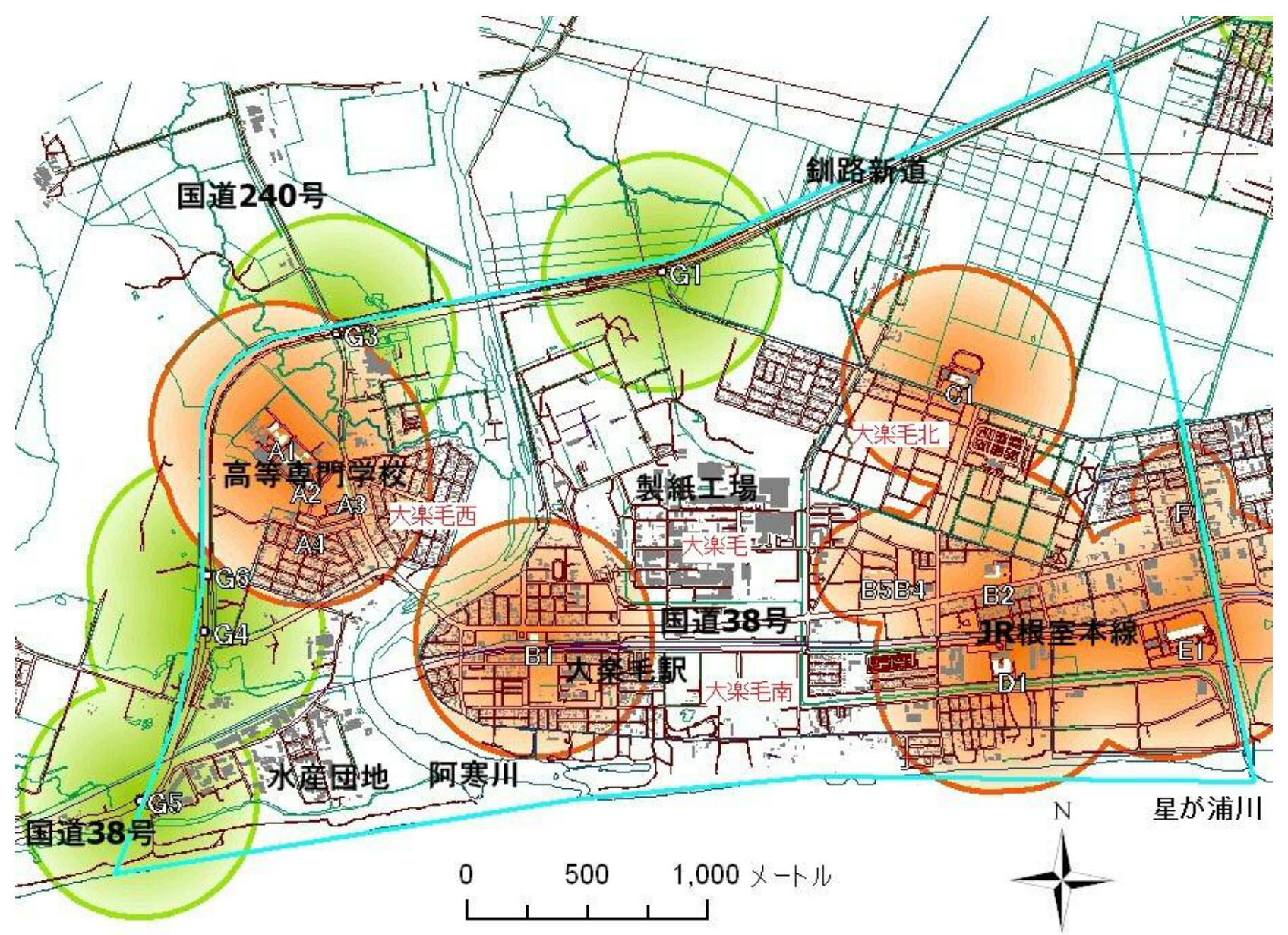

図-6 大楽毛地区の避難場所と避難可能範囲

物を活用することの可能性について検討する.

予備調査の結果, 本研究での対象地区は図-1の(1), (2)とした. (1)は大楽毛西·大楽毛·大楽毛北·大楽毛 南の各町と星が浦北・星が浦大通・星が浦南の各町 のうち星が浦川より西の地区であり，以下，大楽毛 地区と記す。(2)は釧路川右岸の新釧路町 ·川北町 · 古川町・入江町・堀川町であり, 釧路川右岸地区と記 す。大楽毛地区は沿岸の低地であり地区内を流れる 阿寒川がある一方, 避難できるような高い建物が少 ない. 標高は約 $5 \mathrm{~m}$ 程度で最大想定津波のような大 規模の津波が発生した際には地域全体が水没する可 能性がある。釧路川右岸地区は標高が約 $2 \mathrm{~m}$ 以下で あり，堤防高さも低い。 中心市街地から近く比較的 住宅が密集している。高い建物は川沿いには少な く, 川よりやや内陸にはアパート, マンションなど の高い建物があるものの古いものが多い.

\section{（2）現地調査による建物などの選定}

本研究では対象地域と隣接した地域で避難可能な 建物の状況を調べるため現地調査を行なった。大楽 毛地区では山側にバイパス道路である釧路新道の整 備が完了しているため, 釧路新道に架かる橋梁やカ
ルバートも調査対象とした。

現地調査ではレーザー距離計 Nikon LASER1000AS と GPS 機能付きデジタルカメラ CASIO EX-H20Gを用いた。距離計は構造物の高 さを測定するために，デジタルカメラは建物の状況 と位置を記録するために用いた。距離計による高さ の測定は，水平距離 10 50m 離れた位置で建物の壁 面上端から 30 50cm 低い位置を照準して測定した。 得られた值に, 測定者の目の高さを加えた值を建物 の高さとした. GPS 機能付きデジタルカメラで撮影 した写真には位置情報が付属しているため, 地図上 に撮影位置を表示させて確認することができる。ま た, 測定した建物について, 屋上の状況, 外階段など により外部からの避難が可能かどうかなどを可能な 範囲で調査した。

北海道防災会議による最大想定津波では大楽毛地 区の沿岸部で浸水深約 $10 \mathrm{~m}$, 釧路川右岸地区におい て浸水深約 $8 \mathrm{~m}$ になると想定されている。そのため, 大楽毛地区では高さ $15 \mathrm{~m}$ 以上，または $12 \mathrm{~m}$ 以上で 屋上のある建物を選定する。その理由としては，建 物の高さを 1 階当たり $3 \mathrm{~m}$ と仮定すると, 浸水深 $10 \mathrm{~m}$ の場合 4 階だと $3 \times 4=12 \mathrm{~m}$ の高さとなるが, 4 
表-5＼cjkstart選定した避難場所（釧路川右岸地区）

\begin{tabular}{|c|c|c|c|c|c|c|c|c|}
\hline 町区分 & コード & 建物の高さ $(\mathrm{m})$ & 建築物区分 & \begin{tabular}{|l|} 
屋上の有無 \\
\end{tabular} & $\mathrm{L} 1$ & $\mathrm{~L} 2$ & 避難可能距離 & 建設年(1980年以降) \\
\hline 新徐路町 & $\mathrm{H} 1$ & 8.8 & 共同住宅 & 0 & 501 & 101 & 101 & 不明 \\
\hline 机理川路山! & $\mathrm{H} 2$ & 8.4 & 共问俚七 & 0 & 501 & 115 & 115 & 不明 \\
\hline \multirow{14}{*}{ 川北町 } & I1 & 10.8 & 工場 & $\mathrm{O}$ & 501 & 168 & 168 & 0 \\
\hline & I2 & 21.5 & \multirow{13}{*}{ 共同住宅 } & 0 & 501 & 299 & 299 & 0 \\
\hline & I3 & 11.0 & & $x$ & 501 & 101 & 101 & $x$ \\
\hline & I4 & 11.0 & & $x$ & 501 & 105 & 105 & $x$ \\
\hline & I5 & 11.0 & & $x$ & 501 & 90 & 90 & $x$ \\
\hline & I6 & 11.0 & & $x$ & 501 & 93 & 93 & $x$ \\
\hline & I7 & 11.0 & & $x$ & 501 & 95 & 95 & $x$ \\
\hline & I8 & 11.0 & & $x$ & 501 & 97 & 97 & $x$ \\
\hline & I9 & 13.0 & & O & 501 & 99 & 99 & $x$ \\
\hline & I10 & 11.6 & & 0 & 501 & 113 & 113 & $x$ \\
\hline & I11 & 15.0 & & $x$ & 501 & 133 & 133 & $x$ \\
\hline & I12 & 15.0 & & $x$ & 501 & 138 & 138 & $x$ \\
\hline & I13 & 11.0 & & $x$ & 501 & 136 & 136 & 0 \\
\hline & I14 & 13.8 & & $x$ & 501 & 155 & 155 & $x$ \\
\hline \multirow{11}{*}{ 堀川町 } & J1 & 10.6 & \multirow{11}{*}{ 共同住宅 } & $x$ & 501 & 99 & 99 & $x$ \\
\hline & J2 & 10.6 & & $x$ & 501 & 130 & 130 & $x$ \\
\hline & J3 & 10.6 & & $x$ & 501 & 120 & 120 & $x$ \\
\hline & J4 & 10.6 & & $x$ & 501 & 106 & 106 & $x$ \\
\hline & J5 & 11.1 & & $x$ & 501 & 118 & 118 & 0 \\
\hline & J6 & 11.1 & & $x$ & 501 & 119 & 119 & $\mathrm{O}$ \\
\hline & J7 & 20.6 & & 0 & 501 & 212 & 212 & 0 \\
\hline & J8 & 10.6 & & $x$ & 501 & 90 & 90 & $x$ \\
\hline & $\mathrm{J} 9$ & 13.6 & & $x$ & 501 & 155 & 155 & $x$ \\
\hline & J10 & 14.0 & & 0 & 501 & 177 & 177 & $x$ \\
\hline & J11 & 20.4 & & 0 & 501 & 312 & 312 & $x$ \\
\hline \multirow{3}{*}{ 古川町 } & $\mathrm{K} 1$ & 16.0 & \multirow{2}{*}{ 処理施設 } & $x$ & 501 & 381 & 381 & $x$ \\
\hline & K2 & 14.0 & & $x$ & 501 & 131 & 131 & $x$ \\
\hline & K3 & 9.8 & 共同住宅 & 0 & 501 & 68 & 68 & 不明 \\
\hline \multirow{3}{*}{ 入江町 } & L1 & 12.6 & 病院 & $\mathrm{O}$ & 501 & 116 & 116 & $\mathrm{O}$ \\
\hline & L2 & 18.8 & \multirow{2}{*}{ 共同住宅 } & $x$ & 501 & 173 & 173 & 0 \\
\hline & L3 & 21.6 & & $x$ & 501 & 283 & 283 & 0 \\
\hline 光陽町 & M1 & 12.4 & 小学校 & $\mathrm{O}$ & 501 & 195 & 195 & 0 \\
\hline \multirow{13}{*}{ 双葉町 } & N1 & 12.6 & 小学校 & 0 & 501 & 210 & 210 & 0 \\
\hline & N2 & 13.2 & 役所 & 0 & 501 & 139 & 139 & 0 \\
\hline & N3 & 13.2 & 病院 & $x$ & 501 & 239 & 239 & $x$ \\
\hline & N4 & 15.0 & \multirow{10}{*}{ 共同住宅 } & 0 & 501 & 259 & 259 & 0 \\
\hline & N5 & 14.6 & & $x$ & 501 & 338 & 338 & 0 \\
\hline & N6 & 14.6 & & $x$ & 501 & 338 & 338 & 0 \\
\hline & N7 & 14.6 & & $x$ & 501 & 338 & 338 & 0 \\
\hline & N8 & 14.6 & & $x$ & 501 & 338 & 338 & 0 \\
\hline & N9 & 14.6 & & $x$ & 501 & 338 & 338 & 0 \\
\hline & $\mathrm{N} 10$ & 14.6 & & $x$ & 501 & 338 & 338 & 0 \\
\hline & $\mathrm{N} 11$ & 14.6 & & $x$ & 501 & 338 & 338 & O \\
\hline & $\mathrm{N} 12$ & 14.6 & & $x$ & 501 & 338 & 338 & 0 \\
\hline & N13 & 14.6 & & $x$ & 501 & 338 & 338 & 0 \\
\hline \multirow{4}{*}{ 松浦町 } & 01 & 10.8 & & $\mathrm{O}$ & 501 & 130 & 130 & 0 \\
\hline & $\mathrm{O} 2$ & 14.6 & \#同往完 & 0 & 501 & 214 & 214 & 0 \\
\hline & $\mathrm{O} 3$ & 12.6 & 共问俚乇 & 0 & 501 & 70 & 70 & $x$ \\
\hline & 04 & 12.6 & & $x$ & 501 & 104 & 104 & 0 \\
\hline & P1 & 13.4 & & $\mathrm{O}$ & 501 & 105 & 105 & 0 \\
\hline & $\mathrm{P} 2$ & 14.8 & & $\mathrm{O}$ & 501 & 149 & 149 & 0 \\
\hline 川ト町 & P3 & 31.6 & 共同住宇 & 0 & 501 & 346 & 346 & 0 \\
\hline & P4 & 34.6 & 共问俚毛 & 0 & 501 & 253 & 253 & 0 \\
\hline & P5 & 24.6 & & 0 & 501 & 277 & 277 & $\mathrm{O}$ \\
\hline & P6 & 16.6 & & 0 & 501 & 162 & 162 & 0 \\
\hline & Q1 & 15.6 & 社会福祉施設 & 0 & 501 & 180 & 180 & 0 \\
\hline & Q2 & 12.0 & 商業施設 & 0 & 501 & 112 & 112 & $x$ \\
\hline & Q3 & 10.6 & 問兼施設 & 0 & 501 & 82 & 82 & O \\
\hline & Q4 & 27.4 & & 0 & 501 & 522 & 501 & 0 \\
\hline 旭町 & Q5 & 21.6 & & O & 501 & 280 & 280 & O \\
\hline & Q6 & 29.2 & 共同住宇 & 0 & 501 & 0 & 0 & $x$ \\
\hline & Q7 & 11.4 & 共问俚毛 & 0 & 501 & 101 & 101 & 0 \\
\hline & Q8 & 12.4 & & $x$ & 501 & 56 & 56 & 0 \\
\hline & Q9 & 21.0 & & 0 & 501 & 301 & 301 & 0 \\
\hline
\end{tabular}

階部分が $1 \mathrm{~m}$ 浸水してしまうため危険である。その ため 4 階で屋上のある建物または 5 階以上の建物を
目安として上記の值を決定した。釧路川右岸地区も 同様の理由で, 釧路川右岸地区では高さ $12 \mathrm{~m}$ 以上ま 


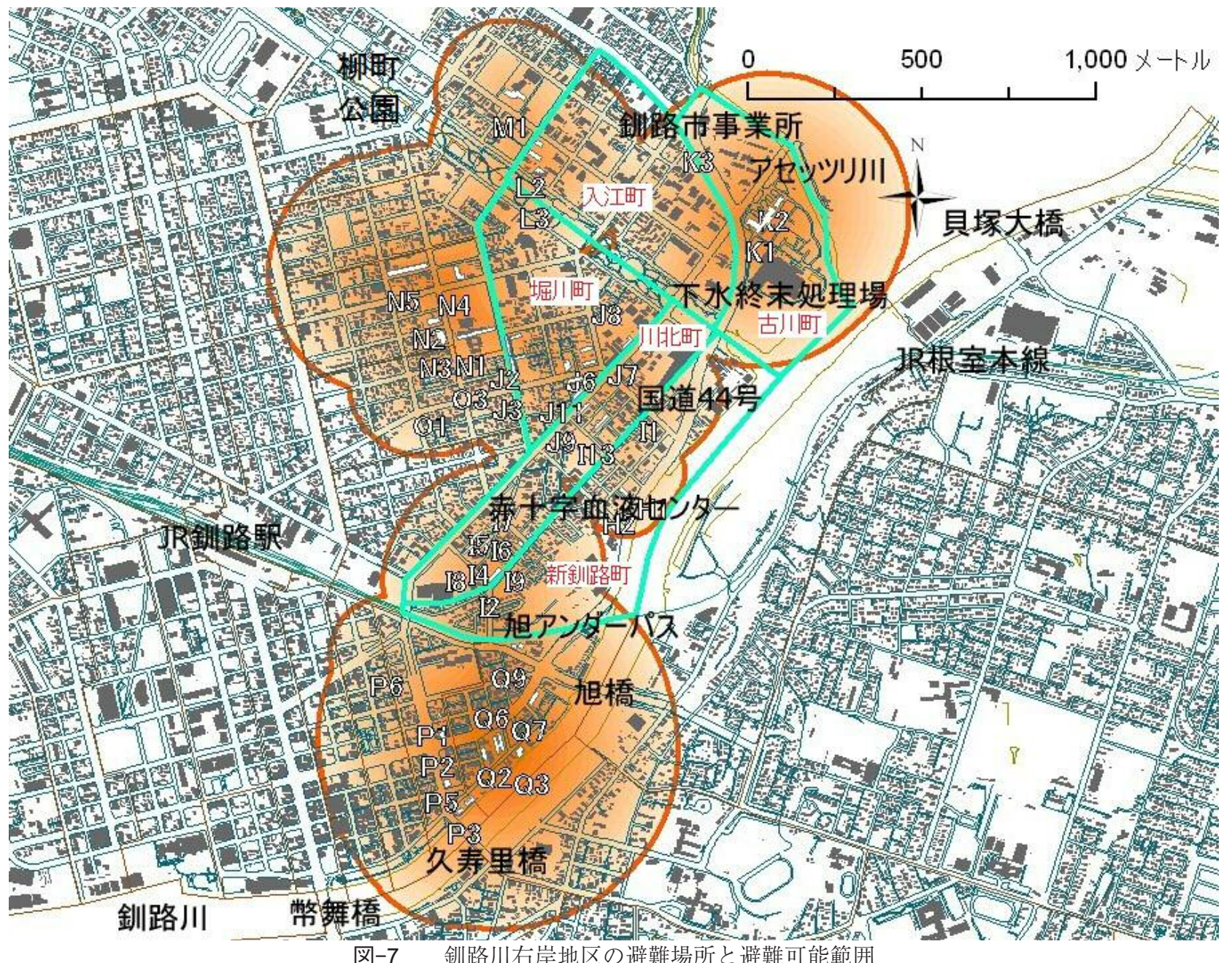

表-6 検討結果のまとめ

\begin{tabular}{|c|c|c|c|c|c|c|}
\hline $\begin{array}{l}\text { 被災 } \\
\text { レベル }\end{array}$ & $\begin{array}{l}\text { 人命の } \\
\text { 損失 }\end{array}$ & $\begin{array}{l}\text { 身体的 } \\
\text { 被害※ }\end{array}$ & $\begin{array}{l}\text { 家財の } \\
\text { 損害 }\end{array}$ & $\begin{array}{l}\text { 日常生活 } \\
\text { への影響 }\end{array}$ & $\begin{array}{l}\text { 対応する地域 } \\
\text { (図-6,7との対応) }\end{array}$ & 主な対応策 \\
\hline 0 & 無 & 無 & 無 & 無 & 被災地域外 & $\begin{array}{l}\text { 救援拠点の整備、浸水地域からの避難路 } \\
\text { 整備 }\end{array}$ \\
\hline 1 & 無 & 無 & 無 & 有 & 浸水しないがライフライン停止 & 避難場所の増設、浸水地域からの避難路 \\
\hline 2 & 無 & 無 & 有 & 有 & $\begin{array}{l}\text { 浸水地域だが避難場所に安全に避難可能 } \\
\text { (図-6,7の避難可能範囲内部) }\end{array}$ & $\begin{array}{l}\text { 避難の徹底、早期の浸水地域外への避難、 } \\
\text { 避難場所での物資の備蓄、浸水地域外 } \\
\text { 避難路整備 }\end{array}$ \\
\hline 3 & 無 & 有 & 有 & 有 & $\begin{array}{l}\text { 浸水地域で避難可能だが、避難先が遠い、 } \\
\text { 避難場所の設備が不十分 } \\
\text { (図-6,7の避難可能範国の外縁部、避難可 } \\
\text { 能範囲で避難場所の設備が不十分な箇所) }\end{array}$ & $\begin{array}{l}\text { 素早い避難、避難場所での物資の備蓄、避 } \\
\text { 難場所の增設、浸水地域外へ避路整 } \\
\text { 借 }\end{array}$ \\
\hline 4 & 有 & - & 有 & 有 & $\begin{array}{l}\text { 浸水地域で避難場所が無い } \\
\text { (図-6,7の避難可能範囲外) }\end{array}$ & $\begin{array}{l}\text { 素早い避難、避難場所の建設、避難場所が } \\
\text { 十分ある地域や浸水地域外ま整備 }\end{array}$ \\
\hline
\end{tabular}

※ 避難行動中の怪我、避難場所に滞在中の病気

たは $9 \mathrm{~m}$ 以上で屋上のある建物を選定した。なお， 建物の選定に際しては，構造上の耐震性や津波に対 する安定性，災害発生時の入口の開放も考慮するこ とが必要であるが，ここでは基礎的検討として高さ のみを基準として選定した。建物の耐震性について は大まかな目安を 1981 年（昭和 56 年）の建築基準
法施行令の改正として, 1980 年発行の住宅地図 ${ }^{25)}$ 利用してそれ以降に建築されたと推定される建物を 後述の表-4, 表-5に○で表した.

また，釧路新道の橋梁については，上記で定めた 高さに達していないものの道路沿いに比較的速やか に避難できる可能性を考慮して, 道路との立体交差 
部を避難場所とした。

\section{（3）避難可能距離の算出と避難可能範囲の可視化}

上述のようにして選定した建物に対する避難可能 距離の算出を行なった。避難する方法としては高い 建物に徒歩で避難すると仮定する。高い建物・高架 橋への避難が可能な範囲の算出方法としては, 文献 26），27）を参考に, 次の式 (1), 式（2）で計算される 距離によって判断する.

$$
\begin{gathered}
L_{1}=P_{1} \times\left(T-t_{1}\right) \\
t_{1}=L_{t} / P_{2}
\end{gathered}
$$

ここで,

$L_{1}:$ 建物への避難可能距離 $(\mathrm{m})$

$P_{1}:$ 歩行速度 $(\mathrm{m} /$ 秒 $)=0.9 \mathrm{~m} /$ 秒

(表-2）28),29)

$T$ ：避難に使用できる時間（秒） $=600$ 秒

$t_{1}$ : 津波が届かない高さへ階段で上る所要時間 (秒)

$L_{t}:$ 津波最大高さ $(\mathrm{m}) \quad$ (表-3)

$\mathrm{P}_{2}$ ：階段昇降速度 $(\mathrm{m} /$ 秒 $)=0.21 \mathrm{~m} /$ 秒 ${ }^{28)}$

$P_{1}$ は文献 28），29）を参考に $0.9 \mathrm{~m} /$ 秒に設定した。 避難に使用できる時間 $T$ は 600 秒（10 分）とする. これは, 北海道防災会議による最大想定津波の予測 到達時間として 31 32 分とされていることと, 参考 文献 30）の調査により，東日本大震災における地震 発生から避難開始までに要した時間は生存者で平均 19 分, 亡くなった方は平均 21 分であったことに基 づく。この避難開始までに要した時間と最大想定津 波の予測到達時間 31 32 分を比較すると, 避難に使 用できる時間 $T=600$ 秒（10 分）はやや安全側の数值 となる。 $t_{1}$ で用いる津波最大波高 $L_{\mathrm{t}}$ は前節で決定し たように表-3の值を用い, 階段・上り昇降速度 $P_{2}$ は 文献 28）を参考にした。ささらに，建物への避難を論 じる場合には，建物の収容力と範囲内の人口も勘案 することも必要なる。本研究では次の式 (3) を用い て建物の概算収容力と周辺の人口密度から避難可能 距離 $L_{2}$ を算出した。

$$
L_{2}=\sqrt{\frac{\frac{C}{D}}{\pi}}
$$

ここで,

$L_{2}$ : 収容力を考慮した建物への避難可能距離（m)

$C:$ 収容可能人数 (人)

$D$ : 地域人口密度 $\left(\right.$ 人 $\left./ \mathrm{m}^{2}\right)$

収容可能人数 $C$ については基盤地図情報 ${ }^{24)}$ で得ら れた建物の面積に対して，避難場所として利用可能 と考えられる階数（屋上が利用可能な場合も屋上も
含む）を乗じ，1名あたりの面積として $3 \mathrm{~m}^{2}$ を除した 值を用いた。 また, 地域人口密度 $D$ は基盤地図情報 に扔ける当該町域の面積と釧路市統計書 ${ }^{23)} に$ に拈りる 当該町域の人口から算出した。

以上で求めた $L_{1}$ 抢よび $L_{2}$ のうち, 值の小さなもの を避難可能距離として取り扱うこととし, 現地調査 で選定した避難場所と避難可能距離を ArcGIS10. 0 に入力して避難可能範囲を可視化した.

GIS に入力する基礎データとして, 国土地理院の 基盤地図情報ダウンロードサービスで提供されてい る基盤地図情報縮尺レベル 25000 を用いた ${ }^{24)}$ 。基盤 地図情報ダウンロードサービスで提供されるデータ に対して, ArcMap 上で対象地域のデータのみを抽出 した，次に，各地区で選定した建物を基盤地図情報 の建築物データから選択してエクスポートすること により避難場所のレイヤを作成した，釧路新道の橋 梁については, 当該位置に新しくデー夕を追加して 建築物と同様の処理を行うこととした。

次に各避難場所を中心とした避難可能範囲を ArcToolBox のバッファを用い可視化する，バッファ の入力フィーチャには, 円の中心となる避難場所の レイヤを選択し, フィールドは上述の避難可能距離 を入力した「避難可能距離」フィールドを選択する. さらにデイゾルブタイプは ALLを選択し, 円が重な り合わないような図形を作成する。図形はグラデー ションにして中心に近いほど濃く表示する。これ は, 避難は直線的に行われるのではなく道のりに沿 うものであるため, 各円の外縁部では条件によって 対象の建物に避難できる可能性が低くなることを感 覚的に表現したものである。

\section{（4）大楽毛地区の避難可能範囲と考察}

表-4 㧍よび図-6 は大楽毛地区に関する避難場所 と避難可能範囲である。図-6に扮いて橙色の円は建 築物に関する避難可能範囲, 緑色の円は橋梁に関す る避難可能範囲となっている.

まず，当地区の地理について説明する，阿寒川が 図の中央やや西側で湾曲しながら南へ流れている. 緑の円を結ぶ道路はバイパス道路の釧路新道で白色 の点が橋梁とボックスカルバートである。釧路新道 はほほ全線が土工で施工されており，阿寒川より西 側は崖に沿って切土と盛土が混在し, 東側は盛土区 間である。釧路新道の北側は農地か湿原であり人家 はほとんどない.

阿寒川は河口近くで西に湾曲しているが，その東 側が大楽毛駅を中心とする市街地である。この市街 地を東西に貫くように JR 根室本線と国道が走って いる。国道は阿寒川を渡った地点で帯広へ向かう 38 
号（西向き）と, 北見方面へ向かう 240 号（北向き） に分かれる。ささらに, この図の範囲より西側の丘陵 上に釧路空港がある。

図-6 中央の避難場所が無い部分は, 製紙工場とそ の敷地である。図中の東側は住宅地, 商業施設, 工 業施設, 農地, 未利用地が混在している。阿寒川西 側の大楽毛西はやや標高が高く, 湾曲部より上流側 は高等専門学校とその周辺は住宅地となっている. 下流側は国道や鉄道より海岸側に水産団地が立地し ている.

次に現地調査で選定した避難場所について考察を 加える. 阿寒川右岸の大楽毛西は地区内ではやや標 高が高く, 高等専門学校の建物など避難可能な場所 も比較的多くある。現状では住宅地の一部が避難可 能範囲から外れるものの, 避難意識の向上でより長 い避難可能時間を確保できれば, 避難場所への避難 は可能と期待できる。 さらにこの地区は，西側の丘 陵上にある釧路空港に近く, 北見方面の内陸部から 釧路に至る国道 240 号線と釧路新道が交差する点で もある.このため発災時の救援拠点を後背の丘陵上 に整備することが今後の検討課題として考えられ る. 一方, 海岸部の水産団地については, 現状では 候補となる避難建物がなかったが, 団地内に緊急的 な避難可能な構造物を設けるとともに, 自動車によ り釧路新道を経て浸水範囲外へ避難することで安全 性を向上させることが期待できる.

阿寒川左岸の大楽毛市街地は, 避難場所として病 院 1 棟（コード B1）が選定された。本研究では駅周 辺の住宅密集地は範囲内になったが, 隣接地域から の受け入れも含めて収容力の詳細な検討がさらに必 要である. 海岸部の大楽毛南は, 避難場所の空白域 になっている。この地域は現状では住宅やその他の 建物も少ないため, 自動車と徒歩を組み合わせて隣 接地域に避難を検討することができると思われる.

調查範囲東側の地域は, 中層の建物が分散して存 在しており, これらを活用することで緊急時の安全 性がある程度確保できると思われる。しかしなが ら，大楽毛北などでは円の外側に住宅地がある部分 もあるので, 避難建物の充実と後背の釧路新道との 効果的な連携を検討する余地がある。全体として当 地区は, 東西 $4.5 \mathrm{~km}$ 南北 $2 \mathrm{~km}$ ほどの範囲であるが場 所により状況が異なる。緊急時に一時避難が可能と 思われる施設の分布にも偏りがあるが, 避難施設の 充実と効果的な自動車での避難も検討することで, 地域の安全性を向上させることが可能と考えられ る.

また, 釧路新道については津波浸水予測図では, 浸水の可能性が指摘されているものの, 周辺より標
高は高く浸水深は浅いため, 効果的に活用すること で地区の安全性を高めることが期待される。中長期 的には道路のかさ上げや, 標高の高い避難場所を隣 接して造成するような対策が考えられる。

\section{（5）釧路川右岸地区の避難可能範囲と考察}

表-5 および図-7 は釧路川右岸地区に関する避難 場所と避難可能範囲である.

まず，当地区の地理について説明する，調査対象 地域は図中の水色線で囲まれた部分であり, 長さ方 向は約 $2 \mathrm{~km}$, 横断方向は約 $1 \mathrm{~km}$ の範囲である. 調査 範囲の東縁は釧路川, 南縁は JR 根室本線, 古川町の 北東縁は釧路川支流のアセッツリ川である。

新釧路町, 川北町, 堀川町は鉄北地区と呼ばれる 地区の一部であり, JR 釧路駅および市中心部は調査 範囲の南西に隣接している, 古川町, 入江町は愛国 地区と呼ばれる地区の一部であり, 鉄北地区と愛国 地区の境界は旧運河を埋め立てた帯状の柳町公園 で, 両地区とも西側に市街地が連なっている.

調査範囲内の東側は釧路川に並行して国道 44 号 線が通過しており, 新釧路町南端の JR 根室本線とは アンダーパスで交差している。アンダーパス内の標 高は海抜 $0 \mathrm{~m}$ 以下である。釧路川を挟んだ対岸は台 地上の地形になっているが, 古川町の北東の貝塚大 橋と新釧路町の南東の旭橋で渡河することとなる.

対象地区内の内, 国道沿線の新釧路町には橋梁工 場や木材加工場があり, 古川町には下水終末処理場 があるものの, それ以外は住宅と中小の商工業施設 などで構成される市街地になっている. 住宅は戸建 住宅, $2 \cdot 3$ 階程度の民間アパート, 中高層の公営住 宅や民間マンションが混在している。 なお, 調査範 囲は図-7 中の水色線で囲った範囲であるが, 隣接地 域に避難可能な建物がある場合は, 当然そちらへの 避難も考えられるため隣接地域の建物についても調 査を行った。

次に現地調査で選定した避難場所について考察を 加える。選定された建物は公営住宅や民間マンショ ンを中心に 67 棟であった。 新釧路町, 古川町, 入江 町には選定された建物は少ないが, 隣接地域にある 建物の避難可能範囲内に入っており, 調查範囲全体 で空白はほとんど無くなっている，したがって当地 区では本研究で取り上げたような共同住宅などを避 難場所にすることで,「命を守る」防災を達成できる と期待できる。ただし，川北町や堀川町の共同住宅 では建設年が古い建物が多いため, 建物の構造や耐 震性および利用状況に応じた収容力に関する詳細な 検討も具体策を策定する際には必要である。

また，実際にこれらの建物を緊急時の一時的な避 
難施設として活用するためには，避難時の入口の開 放などの具体的な手順についても検討が必要にな る. 通常は一般の住宅となっているため, 食料など の物資の備蓄や冬季間など避難者が避難場所に長時 間留まることが難しい場合には，多数の避難者を速 やかに救出する方法についても検討が必要であろ う。このような点について, 津波避難の基本的な目 標地点は安全な高台であるとの考えに立てば，避難 道路についても検討する必要がある，当地区は幹線 国道が海抜 $0 \mathrm{~m}$ 以下を通過することや，東側の高台 に渡る橋が限られていることから地区外への短時間 の避難には課題が多くある。高台への避難道路を新 設することや長期的には居住地域の高台移転の促進 も考慮すべきである。また，当地域には下水処理場 や行政の出先機関, 赤十字血液センターなど, 被災 した場合の影響が大きい施設も点在している。これ らの施設については, 個別に高い津波対策を施すこ とが必要であろう。

\section{（6）検討結果のまとめ}

本研究では, 釧路市のうち大楽毛地区と釧路川右 岸地区を対象範囲として, 現地の状況に基づく既存 構造物への津波に対する避難可能性を検討した。津 波によって受ける被害を人命, 怪我や病気, 家財の 損害, 日常生活への影響に分けて階層化し，それぞ れのレベルに対して上記の検討結果を整理して表-6 を作成した。表-6では被災地域外をレベル 0 とし, 直接浸水しない地域でもライフラインの停止などで 影響を受ける地域をレベル 1 , 浸水地域で安全に避 難ができ, 避難先で食料や物資が利用可能で人命や 身体への被害がほとんど無い場合をレベル2, 避難 中に津波に遭遇して怪我をしたり避難先の環境が不 十分で病気になる人が発生する場合をレベル 3 , 避 難できずに死者が発生する場合をレべル４とした．

図-6, 図-7で対象とした地域は全域で浸水が予測 されるのでレベル 2 以上となる。 このうち, 図中で 色づけされた範囲は安全に避難可能と考えられるた めレベル 2 となる。このような地域では, より確実 に避難できるよう訓練の徹底や，避難中に必要な物 資の充実が対応策の中心となるだろう。また，早期 に浸水地域外に避難ができればより安全性が向上す るので避難路の整備も考えられる. 次に色づけされ た範囲の外縁部は場合によっては避難行動が完了す る前に津波が到来する可能性がありレベル 3 と考え られる。このような場合には, 式 (1) の避難に使用 できる時間 $T$ を長くするために素早く避難を行うと ともに, 避難場所の増設も検討されるべきである. 図-6, 図-7で避難可能範囲外となった場所は現状で
はレベル 4 となるが, レベル 3 と同様の迅速な避難 や避難場所の設置で安全性の向上を図るほか, 避難 場所が十分ある隣接地域へ自動車などで迅速に避難 できるよう避難路の整備も有効と考えられる。避難 場所の建設が有効であることは明らかだが, そのよ うな対策が短期的に難しい場合でも, 避難時間 $T$ が より長くなれば, 避難可能範囲が広がるためレベル 3, 4 はより安全なレベルへの移行が期待できる.

本研究では釧路市内の一部地区を対象として調查 を行ったが, 他の地区でも比較的容易に同様の検討 を行うことができるため, 本研究の手法は都市全体 の津波減災対策を進める上でも有効と考えられる。

\section{4. おわりに}

本研究は釧路市を対象として, その地理的特徵と 既往の津波災害ならびに2 012 年に公表された最大 の想定津波について纒めるとともに, 今後の総合的 な減災対策の構築に向けた基礎的な検討を行ったも のである。釧路市では明治期以降は人的被害を伴う 津波災害は報告されていないものの, それ以前には 大規模な津波が発生した可能性があり，それは2012 年の津波浸水予測と整合的であった。

今後の減災対策として, 既存の建築物や道路施設 を緊急で一時的な避難場所として用いることについ て市内の大楽毛地区と釧路川右岸地区を対象に現地 調査を踏まえた検討を行った。 その結果, 各地点の 地理的条件は異なるものの, 建物への一時的な避難 や自動車による道路施設への避難を効果的に行え ば，人的被害を防止することは拉拉む称可能と思わ れる結果となった。既存の建物などを避難場所とし て活用するためには個別に具体的な検討と取り組み が必要であり, 市民のより深い理解と積極的な取り 組みが望まれる。一方, 避難建物や避難道路の整備 は必ずしも十分な水準ではなく, 長期的には都市構 造を抜本的に見直す必要もあると思われ今後の課題 である。また，冬季間の対策についても別途検討が 必要である。

謝辞: 本研究の実施にあたり, 北見工業大学の早川 博准教授には GIS の取り扱いについてご指導いただ きました。北見工業大学の伊藤陽司准教授, 高橋清 教授, 渡邊康玄教授には示唆に富む有益な助言をい ただきました。東邦コンサルタント(株)の工藤英雄 氏, 釧路市立博物館の戸田氏には貴重な情報を提供 いただきました。ここに記して感謝申し上げます。 


\section{参考文献}

1）北海道防災会議地震火山対策部会地震専門委員会：北 海道太平洋沿岸に係る津波浸水予測図について, http:/ /www.pref.hokkaido.lg.jp/sm/ktk/bsb/tunami/index.htm, 2012.（2012 年 7 月 1 日閲覧)

2）国土地理院: 電子国土基盤図, http://portal.cyberjapan.jp /site/mapuse/index.html, 2009.（2012 年 8 月 21 日閲覧）

3）釧路市：釧路市勢要覧 2012, http://www.city.kushiro.ho kkaido.jp/www/contents/1339631654627/files/youran2012 _all.pdf, 2012.（2012 年 9 月 20 日閲覧）

4) 気象庁：チリ地震被害報告, 気象庁技術報告第 8 号, 1961.

5）第一管区海上保安本部：第一管区海上保安本部調査報 告, 1968 年十勝沖地震調査報告, pp275-306, 1968.

6）都司嘉宣, 荒井賢一：北海道東方沖地震の津波, 平成 6 年文部省科学研究費総合研究 (A) 突発災害 (NO. 06306017)調査研究成果報告書 平成 6 年(1994)北海 道東方沖地震およびその被害に関する調査研究, pp181-190, 1995.

7）北海道建設部：過去に発生した道内各地域の主な地震 被害, http://www.pref.hokkaido.lg.jp/kn/ksd/jisshinhigai.h tm, 2011。（2012 年 8 月 21 日閲覧）

8）岡田成幸, 豊田信博：1994 年北海道東方沖地震に対す る地域行政体の対応, 平成 6 年文部省科学研究費総合 研究(A)突発災害(NO. 06306017)調査研究成果報告書 平成 6 年(1994)北海道東方沖地震およびその被害に関 する調査研究, pp. 197-210, 2005.

9) 平成 15 年十勝沖地震北海道災害対策釧路地方本部: 平成 15 年 $(2003$ 年) 十勝沖地震に係る対策及び被害, 釧路総合振興局, http://www.kushiro.pref.hokkaido.lg.jp/ ts/tss/bousai/H15tokatiokihigai.pdf， 2003。（2012 年 8 月 21 日閲覽)

10）警視庁：平成 23 年(2011 年)東北地方太平洋沖地震の 被害状況と警察措置，警察庁緊急災害警備本部広報資 料, http://www.npa.go.jp/archive/keibi/biki/higaijokyo.pd f, 2012.（2012 年 9 月 12 日閲覧)

11）釧路市測量設計事業協会：平成 23 年東北地方太平洋 沖地震津波 浸水状況調査, 2011 .

12） NHK 札幌放送局：北海道クローズアップその時 どう逃げ切るか 〜津波新想定の衝撃〜，2012 年 9 月 7 日放送, http://www.nhk.or.jp/sapporo/kitakuro/archives/2 012.html\#120907, 2012.

13）澤田恭平：釧路市における地震 - 津波痕跡, 釧路市立 博物館報, No. 409, pp. 3-5, 2012 .

14）佐藤直太郎：続·佐藤直太郎郷土研究論文集, 釧路叢 書第 9 巻, 釧路市, 1968.

15）高清水康博：北海道における津波に関するアイヌの口 碑伝説と記録, 歴史地震, 第 20 号, pp. 183-199. 2005.
16）七山太, 牧野彰人, 佐竹健治, 古川竜太, 横山芳春, 中川充：釧路市春採湖コア中に認められる, 千島海溝 沿岸域における過去 9000 年間に生じた 20 層の津波 イベント堆積物, 活断層・古地震研究報告, No. 1, pp. 233-249, 2001.

17）添田雄二, 七山太 : 北海道東部太平洋沿岸, 春採湖コ ア中に認められる急激な古環境変化と巨大地震津波 との関係, 地学雑誌, vol. 114 (4), pp. 626-630, 2005.

18）澤四朗, 西幸隆, 松田猛: 釧路市大楽毛砂丘の遺跡に ついて, 釧路市立郷土博物館紀要, 第 9 輯, pp. 37-42, 1982.

19）佐藤尚：釧路川紀行, 釧路新書 2 , 釧路市, 1977.

20）長沼孝, 榎森進, 田端宏, 三浦泰之, 池田貴夫, 越田 賢一郎：北海道の歴史〈上〉古代·中世·近世編, 北 海道新聞社, 2011.

21）釧路市：釧路市地域防災計画ダイジェスト版, http://w ww.city.kushiro.hokkaido.jp/www/contents/117990532123 9/files/digest1104.pdf, 2007.（2012 年 9 月 20 日閲覧）

22）釧路市：500 年間隔地震津波ハザードマップ, http://w ww.city.kushiro.lg.jp/common/000008812.pdf, 2012. (2013 年 2 月 8 日閲覧)

23）釧路市：平成 23 年釧路市統計書, http://www.city.kush iro.hokkaido.jp/icity/browser?ActionCode $=$ content $\&$ Conte $n t I D=1148520703145 \&$ SiteID $=0 ， 2012 . （ 2012$ 年 9 月 20 日閲覧）

24）国土地理院：基盤地図情報ダウンロードサービス, htt p://fgd.gsi.go.jp/download/\#，2012.（2012 年 9 月 1 日閲 覧)

25）日本地図編集社：釧路市住宅明細地図昭和 55 年度版, 1980.

26）津波避難ビル等に係るガイドライン検討会, 内閣府政 策統括官 (防災担当) : 津波避難ビル等に係るガイド ライン, 2005.

27）大塚久哲, 筬島隆司, 梶田幸秀, 山崎智彦 : 立地条件 を考慮した東北地方太平洋沿岸地域の津波避難支援, 土木学会論文集 A1(構造·地震工学), Vol. 68, No. 4(地 震防災工学論文集第 31-b 巻), pp. I_1081-1090, 2012.

28）足立啓, 小松和郎, 荒木兵一朗：障害者を考慮した住 宅団地の研究(その1)歩行行動から見た障壁の分析, 日本建築学会大会学術講演梗概集計画系 55(建築計 画・農村計画), pp. 1233-1234, 1980.

29）芳村隆史, 早瀬秀雄, 荒木兵一郎：視覚障害者の安全 歩行空間計画に関する研究（その4）駅構内における 歩行追跡調査, 日本建築学会大会学術講演梗概集計画 系 55(建築計画・農村計画), pp. 1229-1230, 1980.

30）株式会社ウェザーニューズ：東日本大震災 津波調査 (調査結果), http://weathernews.com/ja/nc/press/2011/pdf /20110908_1.pdf,2011。（2012 年 8 月 21 日閲覧） 
(2012. 11. 16受付，2013. 2. 8修正，2013. 2. 23受理)

\title{
A BASIC STUDY OF TSUNAMI EVACUATION TO SHELTER BUILDINGS AND CIVIL STRUCTURES IN KUSHIRO CITY
}

\author{
Yasunori MIYAMORI, Kota UCHIUMI, Toshiaki SHIMIZU, Shintaro YAMASAKI \\ and Hisanori OTSUKA
}

We discuss evacuation planning from tsunami disasters in Kushiro City. The city has not experienced severe tsunami disasters since the recorded history of the 19th century. However, "Ainu", an aborigine of Hokkaido, has been brought down past severe tsunami disasters by word of mouth. In addition, geological evidences indicate them as well. The Hokkaido Prefectural Government announced new data and maps obtained by the tsunami simulation that is reconstructed on account of the geological evidences of the past huge tsunami disasters. We performed on-site investigation by using geographical survey, and used GIS analysis. Then, we concluded that survivability will increase without new evacuation buildings for tsunami disasters if we use tall buildings and elevated highways which have been used, as temporal evacuation sites. 